Ambiances

anbiances Environnement sensible, architecture et espace urbain

$7 \mid 2021$

Staging Atmospheres: Theatre and the

Atmospheric Turn - Volume 2

\title{
Invisible Theatre: militarized space and the staging of affective atmospheres
}

Théâtre invisible: espaces militarisés et mise en scène d'atmosphères affectives

\section{Leah Lovett}

\section{OpenEdition}

\section{Journals}

Electronic version

URL: https://journals.openedition.org/ambiances/3965

DOI: $10.4000 / a m b i a n c e s .3965$

ISSN: 2266-839X

Publisher:

Direction Générale des Patrimoines - DAPA - MCC, UMR 1563 - Ambiances Architectures Urbanités (AAU)

Electronic reference

Leah Lovett, "Invisible Theatre: militarized space and the staging of affective atmospheres", Ambiances [Online], 7 | 2021, Online since 22 December 2021, connection on 24 December 2021. URL: http:// journals.openedition.org/ambiances/3965 ; DOI: https://doi.org/10.4000/ambiances.3965

This text was automatically generated on 24 December 2021.

Ambiances is licensed under a Creative Commons Attribution-NonCommercial-NoDerivatives 4.0 International License. 


\title{
Invisible Theatre: militarized space and the staging of affective atmospheres
}

Théâtre invisible : espaces militarisés et mise en scène d'atmosphères affectives

\author{
Leah Lovett
}

\section{Introduction}

1 In Encountering Affect, Anderson (2014) casts light on the staging of affective atmospheres and the ambiguous ways in which they contribute to shape encounters and spatial relationships both within and beyond the event of their staging. His signal case study for exploring how atmospheres are produced and experienced as collective affects, from groupings of people and things, is a 2010 training exercise delivered as part of the UK state preparation and planning for emergencies. ${ }^{1}$ Though not recognised as such, Anderson's observations of that exercise reveal its basis in Forum Theatre, part of the system of Theatre of the Oppressed techniques developed by Brazilian theatre director Augusto Boal (1931-2009) with the aim of transforming society in the direction of the liberation of the oppressed. In keeping with Boal's model, the session was conceived as a rehearsal for a possible future scenario (in this case, an explosion) played out by actors who interrupted their performance at key points to elicit actionable responses from the audience: 'What would you do?' (Anderson, 2014, p. 155). Anderson recalls the 'nervous excitement' these interruptions produced, linking that collective affect with the apparatus of post-Cold War state security amidst Bush and Blair's War on Terror. However, the assimilation of Boal's theatrical method as a civil contingencies training technique suggests a connection to another, different state apparatus of militarised power with the Cold War and the US-backed Brazilian military regime (1964-1985).

2 This article sets out to investigate the circumstances surrounding Boal's development of the Theatre of the Oppressed method in light of Anderson's (2014) discussion of 
affective atmospheres as mediating experiences of more enduring and dominant 'structures of feeling'. If structures of feeling extend across space and time to place limits and pressures on encounters, then affective atmospheres accrue in the moment around and between bodies to mediate how structures of feeling may be felt (Anderson, 2014, p. 115). Some of Boal's earliest Theatre of the Oppressed experiments took place during his first year of political exile in Argentina (1971-1976), with the unmarked insertion of dramatic scenes into the already populated spaces of the city. Boal (2000, p. 122) subsequently defined Invisible Theatre as, 'the presentation of a scene in an environment other than the theatre, before people who are not spectators,' incorporating it into the Theatre of the Oppressed system as a practical method for 'making oppressions visible' (Boal, 1980, p. 85). Through critical contextual analysis of his first known Invisible Theatre performance, RESTAURANT TEATRO: 'La Ley' [Restaurant Theatre: 'The Law'] (Buenos Aires, 1972), I ask whether the technique offers a model for staging affective atmospheres to infiltrate and inflect dominant structures of feeling. Equally, how might theories of affective atmosphere bring the profound ambiguity of Boal's interventions in the urban environment into focus in ways that open Invisible Theatre up to critical and creative reinterpretation?

3 Recent debates amongst practitioners and theatre scholars highlight Invisible Theatre's 'backseat position' within the Theatre of the Oppressed and attributes this to a less repressive political atmosphere making the practice irrelevant (Villas Bôas, 2019, p. 165-166; see also Kohtes, 1993, p. 85-89). This relegated position may also reflect the development of Theatre of the Oppressed, with Forum Theatre coming after and effectively superseding Invisible Theatre (Boal, 1992, p. 17-18). Another methodological challenge for researchers and theatre critics concerns the contingent invisibility of the technique, resulting in the limited availability of documentation beyond Boal's own accounts of events. Reading those accounts in light of spatial theories of affective atmosphere reveals the inconsistencies in his recollection and framing of the technique. I argue that Invisible Theatre has tended to be overlooked by researchers and practitioners because it never functioned straightforwardly, as Boal claimed it did, according to the binary opposition of oppressor and oppressed. Drawing on archival and performance-led research into the origins of Theatre of the Oppressed conducted in the UK, Brazil and Argentina between 2011-2018, this paper advances an alternative, critical account. ${ }^{2}$ Specifically, it investigates the possibility that Invisible Theatre appeared as an expression of grief and fear, understood here in relation to militarised structures of feeling conveyed through state apparatus of censorship, incarceration and surveillance. Far from negating the technique after the event, I suggest this atmospheric contingency makes Invisible Theatre especially relevant to current debates around the production and dispersal of affective atmospheres in the built environment, and the ongoing challenges for artists seeking to create the atmospheric conditions for socio-spatial change.

\section{Restaurant Theatre: 'The Law'}

This is how I imagine it.

A parrilla, Buenos Aires. 1972.

A man enters, takes a seat and orders a simple meal. He eats. When he is done, he nods at the waiter and stands to leave.

'The bill,' the waiter says, 'you haven't paid.' The man answers, 'no, but I was hungry,' then presents his identity card and begins to speak about The Law. 
The atmosphere shifts.

Before long, everyone is talking about the cost of food and low wages, about hospitality. Not everyone. Alone, at a separate table, the director moves the food about his plate and looks on. A smile tugs at the corners of his mouth, but he doesn't say anything. He watches. Maybe this is how it happened.

Boal recounts the 'more or less logical' sequence of events leading up to his first performance of Invisible Theatre in a fascinating interview with playwright and theatre scholar, Abellán (2001, p. 187):

In Buenos Aires, I did a play in favour of a law that existed, which stated no Argentinian could die of hunger. If an Argentinian was hungry then, by law, he had the right to enter any restaurant, order any food [...] We did a play in which this occurred; I helped to write it: we rehearsed it and, when we were going to do it in the street, my Brazilian friends told me: ‘Don't go, because you could be arrested by the police. And if they arrest you, it won't be a problem for the Argentinians [...] but they could force you to return to Brazil. Don't go.'3

5 He goes on to explain that one of the actors had the idea of representing the play in a restaurant without telling anyone it was theatre so that, 'if the police come, you were just eating.' Before considering how far Invisible Theatre therefore emerged as an affective expression of, and reaction to, militaristic structures of feeling under successive authoritarian regimes, I want to question whether this particular performance was well-placed to highlight and counteract oppressions in the way Boal claims it did. What were the implications of moving a piece of theatre addressed to the problem of hunger from the street into the restaurant, both in terms of the atmospheric affects resulting from such a shift and their capacities to effect meaningful change?

Boal had previously turned to street-theatre in his search for 'the people' as director of the Arena Theatre in São Paolo, where he worked from 1956 until his arrest on vague charges of defaming the government in 1971. One example that tends to come up in the narrative of Theatre of the Oppressed is a piece of agitprop performed for landless workers in the sertão (the 'backlands' of northeastern Brazil) (Boal, 1990a, p. 57). He recalls how, at the end of the play, the actors lifted their prop rifles above their heads and called for revolution. The company was evidently successful in the attempt to excite a revolutionary atmosphere. When the audience responded by inviting them to take up arms against the landowner, however, the actors declined, and explained that the guns that they carried were not real guns. The burning shame of that encounter is implicit in Boal's later acknowledgement that he and the actors, 'were not prepared to fight, but were telling other people to do so' (Boal, 2001, p. 194). This collective, affective experience of shame marked a significant turning point in Boal's practice, prompting him to develop theatrical forms by which the oppressed might 'devise their own solutions' (Cohen-Cruz, 1998, p. 14).

Boal's anecdote reflects his relative status within the socio-spatial structures and street-life of Brazil. By comparison, he recalls how the articulation of his identity in exile limited opportunities for participating in social life in Argentina: 'As an expolitical prisoner, the TV people gave me no work, nor did I ever get a call from the impresarios of the Buenos Aires boulevard. The directors of the state theatres [...] were even less forthcoming' (Boal, 2001, p. 308); 'In Argentina I had to do something else, and I like to do theatre in the street' (Boal, 2005). The enduring image of the street as a space of creative freedom became established within the European discourse of the 
early twentieth century, particularly through Benjamin's $(1934,2005)$ reading of the flâneur in Baudelaire. Benjamin's spatial imaginary of the city as a site for aimless wandering represents an experience of a European city, Paris, afforded at the intersections of class, gendered and racialised identities. The same imaginary that affords the flâneur freedom to survey the streets renders the street a potentially fearful, alienating place for the subjects of his gaze. ${ }^{4}$ This speaks to a point raised by Vila (2017, p. 24-25) concerning the role of identarian articulations in conditioning how structures of feeling and affective atmospheres may be transmitted and experienced. Vila gives the example of a structure of fear becoming activated when the mediating identity 'foreign' is articulated into an environment organised around white, male identities. As a foreigner and political exile in Argentina, Boal was perceived as a threat to the established order. As such, he came to experience the street as an anxious, threatening environment, more than a site of creative freedom and radical possibility.

However, moving the performance of 'The Law' from the streets of Buenos Aires into the restaurant involved a fundamental shift in meaning, from raising awareness of an unenforced law to invoking that law to alert audiences to the problem of hunger. The problem is not simply that performative non-disclosure of Invisible Theatre prevented spectators from seeing themselves as spectators, as Kohtes (1993, p. 88-89) has clearly shown. In staging the identarian articulation of a man without capital into a space organised around transactional encounters, the performance activated latent structures of feeling as a discursive provocation. While ensuring the performance's symbolic invisibility, that shift also delimited the potential for it to be seen by 'the people dying of hunger,' much less gave them the opportunity to devise alternative solutions. It is unclear from Boal's writing whether the architecture of the restaurant permitted the Invisible Theatre performance in question to be witnessed from the street. Either way, the incidental audiences best placed to participate in the ensuing action -identified in his account as the other diners and the restaurant staff- are unlikely to have been suffering from hunger. If the performance was intended to prevent citizens from starving by raising awareness of certain legal protections, the actors would have been more likely to encounter people who would benefit from this knowledge in the street than in a restaurant.

Any doubts this may raise about how far Invisible Theatre is aligned with Boal's transformative aims become more significant when considering the legislative basis of the performance. In researching the Buenos Aires example, I was unable to find any reference to a law precisely fitting Boal's description. This may be due to the incomplete condition of archives of Argentine legal history, especially with regards to the crucial decades of the 1970s and 1980s. ${ }^{5}$ Another possibility is that Boal meant to refer to the more widely debated legal principle of hurto famélico, literally starvation theft, which establishes necessity as a defence in criminal cases involving the theft of food to prevent starvation (Ossorio, 1974). There is evidence to support this in Técnicas (Boal, 2015). Written during Boal's exile in Argentina, the book includes a chapter on Invisible Theatre and the earliest reference to the performance, Restaurant Theatre: 'The Law', which he suggests, "could only be "enacted" in countries with the same law: Brazil, Argentina, and I don't know what others' (Boal, 1975, 2015, p. 103). ${ }^{6}$ This internationalism seems to point to the unenforceable legal principle of hurto famélico over any local legislation, potentially casting doubts on the specificity of Invisible Theatre to its immediate environment. 
10 While therefore unable to verify the legislative inspiration for this performance, my search uncovered a municipal decree issued in Buenos Aires in 1973 - not long after the performance was first staged - which invites further speculation about the affective and socio-spatial capacities of Invisible Theatre. Decreto Ley 8031/73 prohibits anyone from partaking of the services of a restaurant, hotel, or other establishment where food and drink is served, 'with the intent of not paying, being able to do so' (own translation). This infers those without the ability to pay might resist criminal liability, as per the principle of hurto famélico. Nevertheless, the decree indicates a shift in power towards the proprietor by legislating the right to payment for services rendered. It would also complicate the restaging of the example of Invisible Theatre under discussion in positioning anyone performing the central role with the means to pay for their meal explicitly outside of the law. ${ }^{7}$ It is impossible to know whether the Buenos Aires performance of 1972 contributed to the context for this legislative change, and if so, to what extent. Even so, the introduction of municipal legislation concerning payment in restaurants and bars less than a year after the performance of Restaurant Theatre: 'The Law' was staged in Buenos Aires gives rise to the possibility, at least, that the actors were successful in staging the atmospheric conditions for structural change, but not to their desired ends. Boal (2001, p. 304) insists that, in the restaurant, ' $[t]$ he debate was more intense than it would have been in the street.' What is less clear is whether that intensity of collective feeling was directed with or against the forces of oppression, with or against those starving outside of the restaurant, circled by the debate.

11 The exclusion of the oppressed subjects of Restaurant Theatre: 'The Law' as a consequence of its staging calls Boal's framing of spatial conflict in binary terms of oppressor/ oppressed into question. With Anderson (2016), spaces are more ambiguous and mutable, constituted of myriad affective atmospheres and the structures of feeling that condition how they are felt. The ambiguity of Boal's position gestures towards the multiplicity of intersecting structures of feeling at play. While overtly dramatising the issue of hunger, Boal appears to have arrived at Invisible Theatre as a solution to his own loss of political and cultural agency as above the agency of those absented subjects of the performance. Given his enthusiasm for the law in question -'A beautiful law, a humanitarian law!' - it is striking that Boal considered himself to be exempt from legal protection. Without an Argentinian identity card, he was unable to act, even invisibly.

12 Kohtes (1993) has suggested that Invisible Theatre reflects 'the shock of a sudden loss (or the realization of this loss) of formerly enjoyed liberties.' Noting the similarity of Boal's definition of Invisible Theatre, firstly, to unmarked urban performances by the Arbeiter-Theatre-Bund during the Weimar Republic, and secondly, to the guerrilla theatre of US-based practitioners during the Vietnam War, he concludes that 'a certain political soil' produces the conditions for the (re)emergence of theatre disguised as everyday life. The discussion that follows extends this line of thinking in attending to the atmospheric conditions for, and of Invisible Theatre. What can theories of affective atmosphere reveal about the link between a performance in a restaurant in Buenos Aires and the 'political soil' of Brazil under authoritarianism? To what extent did the example of Invisible Theatre under discussion operate to distort and deflect militarised structures of feeling through the transmission of collective affects? In addressing these questions, I turn now to a different collective space of the political prison to explore 
the capacities of performance to produce affects that mediate and transform how structures of feeling are felt.

\section{The Freedom of Prison}

13 The period following the 1964 coup d'état against President João Goulart's left-wing government (1961-1964) saw a series of sweeping economic reforms and the pronouncement of an 'economic miracle' in Brazil (1968-1973). The other side of this miracle, however, was increasing state repression with a series of Institutional Acts issued by more or less extreme military presidents. Governed by the ideological frontiers of the Cold War, the legislation gave powers to military and civilian authorities to rescind the Constitutional rights of anyone identified as an 'internal enemy'. Though initially targeted at politicians and political institutions, the repressive apparatus of the regime soon multiplied its critics, culminating in the student-led March of the One Hundred Thousand on Rio de Janeiro (1968). In response to this growing and manifest opposition, military President Artur da Costa e Silva (1967-1969) promulgated Institutional Act Number Five (AI-5) on the evening of 13th December 1968. In Brazil's cities, covert operations to identify and silence any possible dissent combined with visible and indiscriminate stop and search campaigns to convince would-be critics that 'clandestine activities were the only viable form of opposition' (Dassin, 1998, p. 52). Suspending habeus corpus, allowing trials to be conducted before military tribunals, and reintroducing the death penalty, AI-5 institutionalised an affective strategy of 'control by terror' (Dassin, 1998). In legislating for the censorship of cultural mediums ranging from journalism to theatre and popular music, the regime extended the limits of its own opposition; the work of practitioners including Boal came to be represented as a threat to national stability.

14 It is against this backdrop that Boal (2001, p. 298) discovered that, "theatre and prison -both limited in time and space- can become synonyms of freedom'. Remembering his time as an inmate in Tiradentes military prison, São Paulo, he describes how:

I went into the collective cell and was greeted by fifteen companheiros [...] Each taught what he or she knew: guitar, French (I learned the rudiments!), the history of the parties (pupils disagreed with the masters...), theatre (with me as teacher!), philosophy, and cooking (I learned how to make feijoada!). People knew capoeira, but we didn't have enough space. (Boal, 2001, p. 298)

15 This convivial image of the collective cell is in stark contrast to the glimpses Boal offers of DOPS, São Paulo, where he was held in isolation and tortured while awaiting trial (Boal, 2013). Within the collective cell, groups of activists, academics, and creative practitioners, thrown together for their resistance to the regime, discovered opportunities for creative and social experimentation. Boal's description indicates how the architecture of Tiradentes prison and the practice of grouping political prisoners together, apart from other convicts, contributed to produce a creative and collaborative atmosphere.

16 Similar accounts by prisoners in varied institutional and geopolitical contexts suggest Boal's experience is far from unique. Detailed military records of political trials carried out under the Brazilian regime reveal instances of prisoners charged with subversive activities including indoctrinating other inmates (Dassin 1998, p. 136). Gramsci was imprisoned on the island of Ustica between 1926-1936, during which time he 
established a scuola dei confinati [school for prisoners] (Mayo, 1999, p. 45-46). His ideas about hegemonic discourse and the potential for a critical consciousness to liberate the oppressed informed Freire's (1996) Pedagogy of the Oppressed, after which Theatre of the Oppressed was named. Mandela's commitment to encouraging dialogue between prisoners as a means of education throughout his twenty-year internment on Robben Island gave rise to the nickname 'Mandela University' (Cheers, 1997). Likewise, Malcolm $\mathrm{X}$ remembers his own imprisonment as a time of being 'truly free' specifically because of the opportunities for learning that it offered (Hayley and Malcolm X, 1973, p. 176).

The tendency of prisoners to adapt to the conditions of captivity has more often been observed for its psychologically damaging effects. In his analysis of the prison as 'total institution,' sociologist, Goffman (1961), describes a 'mode of adaptation' whereby society on the outside, mediated by the institution, is perceived by the inmate as more hostile and threatening than life on the inside. This process of institutionalisation enables the prisoner to build 'as much of a free community as possible' with the limited resources available. Thinking back to Boal's description of Tiradentes prison, the inmates' performative transformation of their shared cell into a space of collaboration and learning highlights the potential of such spatial adaptation. Paradoxically, institutionalisation also operates to puncture and negate the disciplinary function of incarceration. When mediated by the collective affect of conviviality, experienced as a site of creative freedom, Boal's shared prison cell momentarily ceased to function as a state apparatus of social control. Yet, that freedom was 'limited in time and space,' as Boal (2001, p. 298) puts it, by the military dictatorship. With Anderson (2014), we can appreciate how the convivial atmosphere happened in the midst of, and continued to be conditioned by, militarised structures of fear and control. The convivial atmosphere of the cell ruptured this overarching feeling structure, as a pressure valve, expressing a repressed spatial imaginary. Structures of feeling extend beyond and across multiple sites, exerting pressure on the capacities of atmospheres to affect. Invisible Theatre might therefore be understood in terms of the tendency towards spatial adaptation, as an attempt at exciting collective affects to mediate an experience of the city conditioned by exile.

\section{Exile Disintegrates}

On $24^{\text {th }}$ April, 1971, just over two months after Boal's arrest, a letter highlighting repression in Brazil and calling for his release was published in the editorial section of the New York Times (Anderson et al, 1971). He was freed soon after on the understanding that, 'in Brazil they do not arrest the same person twice. The second time they kill you directly' (Boal, 2005). Taking the threat seriously, he fled to Buenos Aires, where his wife Cecília was already staying with her family. Though Argentina's increasing authoritarianism in the lead up to the Dirty War (1976-1983) prompted further moves to Portugal and eventually France, they would not return to live in Brazil until 1986. The language Boal (2001) uses to describe his exile in his autobiography conveys his profound sense of grief and disorientation with the forced move. 'In Argentina,' he recalls, 'the emptiness began,' he 'felt invisible,' unable to recognise himself in the 'deserted mirror'; his 'selves had departed,' leaving behind a 'dead man walking.' For Boal, 'exile disintegrates' the self to reveal the inextricable relationship between the 
individual and the space they inhabit. Cast adrift from familiar surroundings, he suggests, 'you float' (Boal 2001, p. 297-299).

Boal's affective experience of exile finds an unlikely parallel in Caillois' $(1935,1984)$ discussion of mimicry as 'an obsession with space in its derealizing effect'. Having observed the mimetic markings and behaviours of certain insects, and noting the anthropomorphising perspective of existing studies, Caillois dismisses the suggestion that they function as a defensive mechanism. Instead, he proposes mimesis as evidence of a 'temptation by space' (emphasis in the original). With Caillois, space emerges as an active and tangible force: it 'pursues,' 'encircles,' and 'digests'; 'touches the individual directly,' 'envelopes,' 'penetrates,' 'passes through,' and eventually 'replaces' bodies. Although no direct reference to atmosphere is made here, this language closely aligns to Anderson's $(2014 ; 2016)$ depictions of atmospheres that 'envelope' and 'pass through', and structures of feeling that 'pressure' and 'limit'. For Caillois, such 'dark' space registers in people as the effect of a dispossessed mind, whether due to mental disorder or, as in his case, 'an attack of 'legendary psychaesthenia,' deliberately aggravated for purposes of ascesis and interpretation.' The psychoactive drug-induced experience he goes on to describe is remarkably similar to Boal's experience in exile, registering in the sensation of becoming indistinguishable from the environment. This traumatic, affective experience is summarised by Caillois as 'depersonalization through assimilation into space' (emphasis in original).

Caillois was writing in 1935, with Europe about to be overwhelmed by the forces of fascism. In hindsight, his warning against the loss of self through mimesis in terms of a 'descent into hell' (emphasis in original) at the individual level has been seen to anticipate, at the collective level, the mass rallies, concentration camps and gas chambers of Nazi Germany (Leach, 2006, p. 72). Mimicry, for Caillois, represents the terrifying dissolution of the self, with the inability to distinguish the self from the surrounding space, but Boal implies a more complex and reciprocal relationship between the individual and their environment. His feeling of invisibility followed the move from living and working in São Paulo, where he 'made a difference, however minimal', to being an ex-political prisoner in Buenos Aires, where it seemed he could make 'no difference' (Boal, 2001, p. 299). This suggests that a coherent identity depends on the capacities of the individual to affect the spaces that constitute it; to make them different. His theatrical staging of affective atmospheres - which emanate from assemblages, passing through and between people and things - can be understood as articulations of the spaces between bodies. Boal's first experiments with Invisible Theatre might be imagined in this sense as attempts to use mimetic effects to resist being overwhelmed by space, enabling him to redefine the relationship between self and surroundings in exile.

21 Unlike Caillois, whose experience was self-induced, Boal's feelings of loss were an effect of militaristic structures of fear that pursued him across national borders. In relating the urgency of his own invisibility in Buenos Aires, Boal refers to a relationship between Argentinian and Brazilian police. Elsewhere, he clarifies this with reference to a secret intelligence and operations network code-named Operation Condor (Boal, 2001, p. 303), which constituted an agreement between US-supported South American military regimes to coordinate information and resources in order to track, torture and execute political opponents. Though only institutionalised in 1975, this network was developed over several years, remaining almost entirely undetected until the release of 
formerly classified information in the US during the 1990s. Its secrecy was partly ensured through the use of undercover strategies with marked similarities to Invisible Theatre. Identifying precedents to Operation Condor, Sznajder and Roniger (2009, p. 197) describe a technique for the surveillance of Brazilians in Uruguay implemented as early as 1964, whereby military police 'posed as security personnel supplied by the local authorities, supposedly to protect the exiles.' They explain how this practice was repeated in other states in order to infiltrate groups of political activists operating, as exiles, on an international scale. Operation Condor can be understood as implicating military and theatre actors in a shared space of identification, governed by militaristic structures of feeling. Boal (1990b, p. 32) moreover acknowledges the influence of covert military strategies when he reflects that, '[r]udimentary forms of invisible theatre [...] have always existed. In espionage, for instance, spies use techniques such as camouflage, interpretation of roles, and simulated realities - which are all invisible theatre techniques.' From this perspective, the distinction between the actors involved in the Invisible Theatre and those invisible referents of authority, operating undercover, begins to collapse.

There is, though, a crucial difference between agents of military power assuming false identities for purposes of surveillance and the actors of Invisible Theatre playing out their roles unannounced. Although he was probably unfamiliar with the particular strategies being deployed by the military at the time, Boal was aware of the possibility he was being observed. This is significant because surveillance is only effective as a means of exerting control when the surveillant gaze is both known and unverifiable to its subject; it is with the uncertainty of always-maybe being watched by an invisible referent of that power that the disciplining effect of surveillance becomes internalised, as Foucault (1995) has shown. By contrast, as a model of urban performance intended to elude surveillance, Invisible Theatre prevents the audience from seeing itself as such. In an inversion of terms, it is this not-knowing that produces a rupture in the environment and an affective charge. As Anderson (2014, p. 159) observes, 'minor changes, such as a missed note or an out-of-place word, can cause atmospheres to fall apart or fade away or otherwise change.' Compared to the militaristic structures of feeling, enacted across geographies and temporalities, affective atmospheres are more susceptible to subtle interventions. Yet, this fragility also produces creative opportunities. Assimilated into the urban environment, Invisible Theatre is reciprocally constituted through the encounters it provokes. Against the repressive apparatus of a dictatorship established by silencing opposition, it remains determinately open to ambiguity and contradiction.

Invisible Theatre therefore recognises the conditions for dramatic action already exist in strictly non-theatrical contexts. As Boal $(2006$, p. 6) put it: 'The Invisible show can be presented in any location where its drama can really occur or has already occurred'. To realise this is also to acknowledge the inherent instability of the spaces and structures of feeling (militarised or otherwise) conveyed through the built environment. I have been referring to the regime in the singular, but of course it was not singular in practice. Exiled artists and activists including Boal were decisive in their opposition to the dictatorship, but their visibility as cultural practitioners created opportunities in this regard. Spatial theorist, Massey (2005, p. 173) has warned against romanticising the figure of the exile because to do so risks reinvesting individualism and elitism in new guises. For the vast majority of those living in Brazil under dictatorship, visible opposition was unthinkable, not only because of the dangers it entailed, but also 
because opposing structures of dominance requires social, economic and cultural resources, and an identity that makes direct opposition imaginable.

That is not to dismiss the possibility of individuals concealed within and against the regime expressing their ambivalence in ways which, unlike Invisible Theatre, are still easily overlooked. Boal hints at this when he recalls how the judge who had provisionally authorised the São Paulo Fair of Opinions, staged at the Arena Theatre, São Paulo (1968), was subsequently arrested for belonging to a guerrilla organiastion. The following, related to me in 2011 by a lawyer who grew up in Belo Horizonte during the dictatorship, suggests how the scale and structure of the military regime presented opportunities for subversion (my emphasis):

My father was a police officer, and that created a very interesting dynamic, because he was a police officer, now I know, that had very interesting sympathies to the left. So he was a guy in the government, in the machine, but he didn't like the machine. Actually, he was, now I understand, a very liberal guy. So sometimes they would arrest someone and he would find ways of freeing this person, using the laws to say, 'uh-uh, this was an illegal arrest.' [...] And he was not one person, because the government was such a big employer. You had people controlling the machine, but many on the clock working against the machine, inside the machine, who are trying to make the machine more flexible - not to accuse people and destroy people's lives. They are there not because they agree with the ideology, but because they need the money. So they play a double role.

Where the performance of Invisible Theatre in Buenos Aires may have inadvertently contributed to inspire a tightening up of legislation, further disadvantaging the same individuals the actors were supposed to represent, here is anecdotal evidence of a representative of the state using the given apparatus of state repression to delimit their reach.

Invisible Theatre ultimately depends on this urge to intervene when an injustice is perceived to have taken place. The concept of mimicry gestures to the way in which individuals gain social acceptance through identifying, remaining inside, and reasserting the parameters of acceptable attitudes and behaviours within a given context. By rehearsing an already familiar, if flexible, 'script' - whether as a customer in a restaurant, a citizen of the state, an officer in the military, an inmate in a prison cell or even a performer in an invisible theatre troupe - the individual becomes inscribed into their cultural setting. The tendency to conform to normative social influence, even where to do so contradicts inwardly held beliefs, is consistent with the powerful desire to belong to a social group (Nolan et al., 2008; Deutsch and Gerard, 1955; Asch, 1955). Thinking back to the convivial atmosphere of the collective prison cell, that atmosphere emanated from imitative activities to form a cohesive social group within an architectural container. Likewise, actors performing undercover signal their social belonging to the theatre group, but in the more porous context of the city, their actions become entangled with the performative structures already at play in those spaces. The imitative behaviours that structure social interactions and make them smooth tend towards similarity. However, Invisible Theatre involves the calculated rejection of certain normative behaviours (whilst remaining concealed by others) to stage the tangle of conflicts already imbricated into the built environment. In the example of Restaurant Theatre: 'The Law', conflict arises at the point at which the protagonist too-loudly declares his inability to pay the bill. In the act of transgressing the limits and pressures exerted through structures of feeling, Invisible Theatre stages 
affective atmospheres for drawing unsuspecting audiences into the process of their renegotiation.

\section{Conclusion}

Conceived as a 'weapon' within the 'arsenal' of Theatre of the Oppressed, Boal (1979, 2000 , p.6) engages the combative rhetoric of military power to articulate Invisible Theatre in binary and oppositional terms of oppressor/oppressed, visible/invisible, and to align himself with the oppressed. In setting out to investigate the circumstances of the Invisible Theatre performance, Restaurant Theatre: The Law (Buenos Aires, 1972), this discussion has revealed a more ambiguous and entangled relationship with the state apparatus of the Brazilian military regime. My research into Argentine legal history calls the premise of Boal's play as a means of consciousness-raising around the legal rights of starving citizens into dispute, gesturing to the possibility that it may have contributed to produce the context for a subsequent legislative change to criminalise non-payment in bars and restaurants. Rather than presenting an aesthetic solution to economic conditions, the emergence of Invisible Theatre in Boal's practice appears to represent a personal loss in terms of his position within Brazilian society, as Kohtes (1993) has suggested. Anderson (2014) provides a more nuanced way of understanding how Invisible Theatre functioned in practice through rupturing affective atmospheres to mediate militarised structures of feeling. While I consequently reject reductive interpretations of Boal's theatrical system, that is by no means to dismiss the creative force of Invisible Theatre in its capacity to shape encounters in and with the environment. Recognising how the theatrical method has been used to condition collective affects highlights opportunities for even the subtlest interventions into the urban to shape encounters in ways that render structures of feeling visible and maybe even alter how they are experienced. After all, through the staging of affective atmospheres, even a prison may be encountered as a space of freedom.

\section{BIBLIOGRAPHY}

Abellán, Joan. 2001. Boal cuenta Boal. Barcelona: Institut del Teatre.

Anderson, Ben. 2014. Encountering Affect: Capacities, Apparatuses, Conditions. Farnham: Ashgate.

Anderson, Ben. 2016. Neoliberal Affects. Progress in Human Geography, 40(6), p. 734-753. https:// doi.org/10.1177/0309132515613167

Anderson, Robert; Miller, Arthur; Papp, Joseph; Prince, Harold \& Schechner, Richard. 1971. Repression in Brazil. The New York Times, 24 April.

Asch, Solomon E. 1955. Opinions and Social Pressure. Scientific American 193 (5). p. 31-35. 
Barbosa, Fernando de Holanda. 1998. Economic Development: the Brazilian Experience. In: Hosono, Akio \& Saavedra-Rivano, Neantro (eds.). Development Strategies in East Asia and Latin America. London: Palgrave Macmillan. p. 69-87.

Benjamin, W. 2005 [1934]. The Present Social Situation of the French Writer. In: Walter Benjamin. Selected Writings (Volume 2, part 2, 1931-1934 [trans. Rodney Livingstone]. Cambridge, Mass: Harvard University Press. p. 744-767.

Bishop, Claire. 2012. Artificial Hells: Participatory Art and the Politics of Spectatorship. London: Verso. Boal, Augusto 1980. Stop! C'est Magique. Paris: Hachette.

Boal, Augusto. 1990a. Boal in Brazil, France, the USA: An Interview with Augusto Boal. Interview by Michael Taussig and Richard Schechner. TDR, 34, no.3 (1990a). p. 50-65.

Boal, Augusto. 1990b. 'Invisible Theatre: Liège, Belgium, 1978' [translated by Susana Epstein]. TDR, 34, no.3. p. 22-34.

Boal, Augusto. 1992. Games for Actors and Non-Actors [trans. Adrian Jackson]. London and New York: Routledge.

Boal, Augusto. 2000 [1979]. Theatre of the Oppressed. London: Pluto Press.

Boal, Augusto. 2001. Hamlet and the Baker's Son: My Life in Theatre and Politics. [translated by Adrian Jackson and Candida Blaker]. London and New York: Routledge.

Boal, Augusto. 2005. Famed Brazilian Artist Augusto Boal on the "Theater of the Oppressed", interview by Juan Gonzalez. Democracy Now [online]. Available online at: https:// www.democracynow.org/2005/6/3/famed_brazilian_artist_augusto_boal_on (accessed 3 March 2011).

Boal, Augusto. 2006. Aesthetics of the Oppressed [trans. Adrian Jackson]. Oxon: Routledge.

Boal, Augusto. 2013. 'Brecht e, modestamente, eu!' Instituto Augusto Boal. Available online at: http://augustoboal.com.br/2013/06/13/brecht-e-modestamente-eu/. (Accessed 15 December 2021).

Boal, Augusto. 2015 [1975]. Técnicas latinoamericanas de teatro popular: Una revolución copernicana al revés. Buenos Aires: Corregidor.

Caillois, Roger. 1984 [1935]. Mimicry and Legendary Psychaesthenia [trans. John Shepherd]. October, vol. 3. p. 16-32.

Cheers, D. Michael. 1990. Nelson Mandela Reveals Private Side of his Life as a Prisoner for 27 Years. Jet, 77, no.22. p. 12-17.

Cohen-Cruz, Jan (ed.) 1998. Radical Street Performance: An international anthology. London and New York: Routledge.

Dassin, Joan, (ed.) 1998. Torture in Brazil [translated by Jaime Wright]. Austin, Texas: University of Texas Press.

Decreto Ley 8031/73. 1973. Buenos Aires. Available online at: http://www.gob.gba.gov.ar/ legislacion/legislacion/l-8031.html (accessed 7 November, 2013).

Deutsch, Morton \& Gerard, Harald B. 1955. A study of normative and informational social influences upon individual judgment. The Journal of Abnormal and Social Psychology, 51(3), p. 629-636. https://doi.org/10.1037/h0046408 
Foucault, Michel. 1995. Discipline and Punish: The Birth of the Prison [translated by Alan Sheridan]. New York: Random House.

Freire, Paolo. 1968 [1968]. Pedagogy of the Oppressed. [translated by Myra Bergman Ramos]. London: Penguin.

Goffman, Erving. 1961. Asylums: Essays on the Social Situation of Mental Patients and Other Inmates. New York: Anchor Books.

Hayley, Alex \& Malcolm X, 1973. The Autobiography of Malcolm X. New York: Ballantine.

Kohut, David \& Vilella, Olga (eds.). 2016. Historical Dictionary of the Dirty Wars. Lanham and London: Rowman and Littlefield.

Kohtes, Martin Maria. 1993. Invisible Theatre: Reflections on an Overlooked Form. New Theatre Quarterly, 9, no.33.p. 85-89.

Leach, Neil. 2006. Camouflage. Cambridge, Mass.: MIT Press.

Lovett, Leah. 2019. Making a Scene in London and Rio de Janeiro: Invisible Theatre and Urban Performance after Augusto Boal (1931-2009). PhD thesis. London: University College London. Available online at: https://discovery.ucl.ac.uk/id/eprint/10066270/25/

Lovett\%20Vol1\%20MakingAScene2019\%20EDITED_new.pdf (accessed 14 April, 2021).

Massey, Doreen. 2005. For Space. London: Sage.

Mayo, Peter. 1999. Gramsci, Freire and Adult Education. London: ZED Books.

McSherry, J. Patrice. 2002. Tracking the Origins of a State Terror Network: Operation Condor. Latin American Perspectives 29, no.1. p. 38-60.

Nolan, Jessica M.; Schultz, P. Wesley; Cialdini, Robert B.; Goldstein, Noha J., \& Griskevicius, Vladas. 2008. Normative Social Influence is Underdetected. Personality and Social Psychology Bulletin, 34(7), p. 913-923. https://doi.org/10.1177/0146167208316691.

Ossorio, M. 1974. Diccionario de Ciencias Jurídicas, Políticas y Sociales. Buenos Aires: Editorial Heliasta.

Sznajder, Mario \& Roniger, Luis. 2009. The Politics of Exile in Latin America. Cambridge: Cambridge University Press.

Veigel, Klaus Friedrich. 2009. Dictatorship, Democracy, and Globalisation: Argentina and the Cost of Paralysis, 1973-2001. Pennsylvania: Pennsylvania State University Press.

Vila, Pablo. 2017, Music, dance, affect, and emotions in Latin America. New York: Lexington.

Villas Bôas, Rafael. 2019. Invisible Theatre. In: Howe, Kelly; Boal, Julian \& Soeiro, José (eds.). The Routledge Companion to Theatre of the Oppressed, edited by. London: Routledge. https://doi.org/ $10.4324 / 9781315265704$

\section{NOTES}

1. The UK Civil Contingencies Act (2004) places a legal obligation on emergency services and local authorities to assess the risk, plan and exercise for emergencies.

2. This article builds on arguments developed in my doctoral thesis (Lovett, 2019). The research project was funded by the AHRC and UCL Doctoral School.

3. My translation of the Spanish text (Abellán, 2001, p. 187). 
4. Massey (2005) has powerfully argued this point with particular attention to the gendering of space to show how the built environment is subject to uneven relations of power that tend to privilege white, male identities.

5. A combination of political instability and economic crisis kept records low on the agenda of successive administrations. Not only were libraries and archives chronically under-resourced, governments operating in violation of the law had good reason to hide or destroy potentially incriminating records. It may be that details of the law to which Boal refers was lost as a result. For a detailed discussion of issues around archival research in Argentina, see Veigel (2009, p. ix$\mathrm{xi)}$

6. A restaurant performance staged in Chiclayo, Peru (1973) and recounted in Boal (2000) is sufficiently similar to the Buenos Aires performance that they have been read as interchangeable (see, for example, Bishop, 2012, p. 123).

7. Boal (1980, p. 85 ) has suggested that Invisible Theatre should never inflict violence, nor place itself outside of the law.

\section{ABSTRACTS}

This paper revisits the circumstances surrounding Brazilian theatre director, Augusto Boal's first recorded experiment with Invisible Theatre in a restaurant in Buenos Aires (1972) in light of Anderson's (2014) theory of affective atmospheres in their capacity to mediate structures of feeling. Drawing on original archival and performance-based research, I advance a critical account of Restaurant Theatre: The Law through a narrative reimagining of the performance and key evidence concerning the law in question that fundamentally challenges Boal's claims for the technique as a means of social liberation from forces of oppression. The alternative possibility explored here is that Invisible Theatre developed in Boal's practice as an atmospheric reaction to militaristic forms of urban encounter and a means with which to infiltrate structural feelings of fear. This idea is traced through Boal's encounters with state apparatus of affective control as a political prisoner and marked dissident in exile, and with the performative concept of camouflage. Freed from the overdetermining binaries of oppressor and oppressed, I suggest Invisible Theatre can open up opportunities for practitioners seeking to stage affective atmospheres to produce transformative encounters and perceptions.

Cet article revisite les circonstances entourant le premier essai connu de Théâtre Invisible réalisé par le metteur en scène brésilien Augusto Boal (1972) dans un restaurant de Buenos Aires à la lumière de la théorie d'Anderson (2014) sur les atmosphères affectives et leur capacité à médiatiser les structures du sentiment. M'appuyant sur une recherche originale combinant consultation d'archives et recherche-création, je propose un compte-rendu critique de Restaurant Theatre: The Law à travers le récit ré-imaginé de la performance et des preuves essentielles au sujet de la loi en question et qui remettent fondamentalement en cause l'affirmation de Boal que la technique agit comme un outil de libération sociale face aux forces d'oppression. L'alternative explorée ici est que le Théâtre Invisible s'est développé dans la pratique de Boal comme une réaction atmosphérique contre les formes militarisées de rencontres urbaines, conçues de manière à infiltrer un sentiment structurel de peur. Cette idée se retrouve à travers les rencontres de Boal avec les appareils de contrôle affectifs de l'État lorsqu'il est fait prisonnier politique, puis dissident en exil, ainsi que dans le concept performatif de camouflage. Libéré des 
oppositions binaires surdéterminées de l'oppresseur et de l'oppressé, je propose que le Théâtre Invisible offre aux praticiens qui cherchent à mettre en scène des atmosphères affectives la possibilité de produire des rencontres et des perceptions transformatrices.

\section{INDEX}

Mots-clés: atmosphères affectives, structure de sentiments, Théâtre Invisible, régime militaire brésilien, camouflage

Keywords: affective atmospheres, structures of feeling, Invisible Theatre, brazilian military regime, camouflage

\section{AUTHOR}

\section{LEAH LOVETT}

Leah Lovett is an artist and Research Fellow based at University College London, where she completed her $\mathrm{PhD}$ with a practice-research thesis on Invisible Theatre and urban performance after Augusto Boal, funded by the AHRC. She is currently based in the Bartlett Centre for Advanced Spatial Analysis, researching methods of digital co-creation and the use of interactive technologies for telling stories aimed at spatial justice. Her performances and installations have been exhibited across the UK and internationally with partners including the Royal Docks, the City of London Corporation, Wellcome, UP Projects and the Live Arts Development Agency. Contact: 1.lovett@ucl.ac.uk 